\title{
Clinical and pathological aspects of chronic Senecio spp. poisoning in sheep ${ }^{1}$
}

\author{
Paula R. Giaretta ${ }^{2}$, Welden Panziera ${ }^{2}$, Márcia E. Hammerschmitt ${ }^{3}$, Ronaldo \\ M. Bianchi², Glauco J.N. Galiza ${ }^{4}$, Ingrid S. Wiethan ${ }^{3}$, Talissa Bazzi ${ }^{2}$ \\ and Claudio S.L. Barros ${ }^{5 *}$
}

\begin{abstract}
Giaretta P.R., Panziera W., Hammerschmitt M.E., Bianchi R.M., Galiza G.J.N., Wiethan I.S., Bazzi T. \& Barros C.S.L. 2014. Clinical and pathological aspects of chronic Senecio spp. poisoning in sheep. Pesquisa Veterinária Brasileira 34(10):967-973. Departamento de Patologia, Universidade Federal de Santa Maria, Av. Roraima 1000, Camobi, Santa Maria, RS 97105-900, Brazil. E-mail: claudioslbarros@uol.com.br

This paper describes an outbreak of chronic Senecio spp. poisoning in grazing sheep in Rio Grande do Sul, Brazil, causing the death of 10 out of 860 adult sheep. Eight sick ewes were euthanized and necropsied. Cattle from this farm were also affected. Clinical signs included progressive weight loss, apathy and photosensitization. Four out of seven tested sheep had increased gamma-glutamyl transferase serum activity and two of them presented serum elevation of alkaline phosphatase. At necropsy, three out of eight ewes presented slightly irregular toughened livers with multifocal nodules, two out of eight ewes had a whitish liver with thickened fibrotic Glisson's capsule partially adhered to the diaphragm, and three out of eight ewes had smooth and grossly normal livers. Necropsy findings attributed to liver failure included hydropericardium $(7 / 8)$, ascites $(5 / 8)$, icterus $(2 / 8)$, hydrothorax $(1 / 8)$, and edema of mesentery (1/8). The main hepatic histological findings that allowed the establishment of the diagnosis were megalocytosis, proliferation of bile ducts and fibrosis. Spongy degeneration was observed in the brains of all eight necropsied sheep and was more severe at the cerebellar peduncles, mesencephalon, thalamus, and pons. These are suggested as the portions of election to investigate microscopic lesions of hepatic encephalopathy in sheep with chronic seneciosis. The diagnosis of Senecio spp. poisoning was based on epidemiology, clinical signs, laboratory data, necropsy and histological findings.
\end{abstract}

INDEX TERMS: Senecio spp., seneciosis, pyrrolizidine alkaloids, diseases of sheep, pathology, liver, hepatic encephalopathy.

RESUMO.- [Aspectos clínico-patológicos da intoxicação crônica por Senecio spp. em ovinos.] Neste trabalho, relata-se um surto de intoxicação crônica por Senecio spp.

\footnotetext{
${ }^{1}$ Received on September 30, 2014.

Accepted for publication on October 16, 2014.

This paper is part of the requirements for fulfillment of the Master of Science degree by the first author in the Programa de Pós-Graduação em Medicina Veterinária, major in Veterinary Pathology.

${ }^{2}$ Programa de Pós-Graduação em Medicina Veterinária, Patologia e Patologia Clínica, Centro de Ciências Rurais (CCR), Universidade Federal de Santa Maria (UFSM), Camobi, Santa Maria, RS 97105-900, Brazil.

${ }^{3}$ Trainee in Veterinary Pathology, PIBIC fellowship, Laboratory of Veterinary Pathology, UFSM, Santa Maria, RS.

${ }^{4}$ Faculdade de Medicina Veterinária (FMV), Universidade de Cuiabá (UNIC), Av. Beira Rio s/n, Jardim Europa, Cuiabá, MT 78040-500, Brazil.

${ }^{5}$ Departamento de Patologia, CCS-UFSM, Av. Roraima 1000, Santa Maria, RS 97105-900. *Corresponding author: claudioslbarros@uol.com.br
}

em ovinos no estado do Rio Grande do Sul, Brasil. Dez ovelhas adultas de um rebanho de 860 ovinos morreram com sinais da doença e oito que estavam doentes foram eutanasiadas e necropsiadas. Na propriedade, a doença também foi observada em bovinos. Os sinais clínicos nas ovelhas incluíam emagrecimento, apatia e fotossensibilização. Quatro ovelhas, de um total de sete que foram testadas, apresentaram aumento da atividade sérica da gama glutamil transferase e duas apresentaram fosfatase alcalina sérica elevada. Na necropsia, em três dos oito ovinos necropsiados, o fígado estava levemente mais firme, com superfície capsular ligeiramente irregular e com nódulos pálidos na superfície de corte. Em outros três ovinos o fígado era macroscopicamente normal. Em dois dos oito ovinos necropsiados a cápsula de Glisson era brancacenta devido à fibrose e parcialmente aderida ao diafragma. Adicionalmente, 
foram observadas alterações macroscópicas atribuíveis à insuficiência hepática como hidropericárdio $(7 / 8)$, ascite (5/8), icterícia (2/8), hidrotórax (1/8) e edema no mesentério (1/8). Histologicamente, as principais alterações observadas, que contribuíram para o estabelecimento do diagnóstico de intoxicação crônica por alcaloides pirrolizidínicos nas ovelhas deste surto foram hepatomegalocitose, proliferação de ductos biliares e fibrose. Todas as ovelhas apresentavam degeneração esponjosa grave no cerebelo e pedúnculos cerebelares, ponte, mesencéfalo e tálamo. Sugere-se que esses sejam os sítios anatômicos de eleição no encéfalo para a observação dessa lesão em ovinos com intoxicação por Senecio spp. 0 diagnóstico de intoxicação por Senecio spp. foi baseado na epidemiologia, achados clínicos, laboratoriais, de necropsia e histopatológicos.

TERMOS DE INDEXAÇAO: Senecio spp., seneciose, alcaloides pirrolizidínicos, doenças de ovinos, patologia, fígado, encefalopatia hepática.

\section{INTRODUCTION}

Senecio spp. are the most common hepatotoxic plants causing chronic poisoning in livestock in Brazil, being especially important in the South (Tokarnia et al. 2002). Poisoning by Senecio spp. plants are the most important cause of death in adult cattle in central region of the State of Rio Grande do Sul (Lucena et al. 2010).

Sheep are considered markedly resistant to Senecio spp. poisoning either due to peculiarities of their ruminal flora (Craig et al. 1992) or to enzymatic liver complexes (Huan et al. 1998) which result in a remarkable ability to detoxify pyrrolizidine alkaloids contained in these plants. Accordingly, sheep grazing has been generally recommended as a biological control for Senecio spp. (Soares et al. 2000, Bandarra et al. 2012, Karam et al. 2013). Studies have indicated that sheep continuously stocked at 0.43 sheep/hectare (Soares et al. 2000) and 3.0 sheep/ha (Bandarra et al. 2012) can control Senecio spp. in the field. Although rare, however, outbreaks of Senecio spp. poisoning in sheep, have been reported in Brazil (Ilha et al. 2001, Grecco et al. 2011) and the indiscriminate use of sheep to control the plant might not be safe (Dollahite 1972) because sheep held for several years in pastures markedly invaded by Senecio spp. may be affected after ingesting large amounts of the weed (Seaman 1985, Seaman \& Dixon 1989).

Although the practice of controlling Senecio spp. growth by sheep grazing should continue to be encouraged, diagnostic parameters must be established for detecting outbreaks of pyrrolizidine alkaloids poisoning in sheep, allowing for avoiding further losses. The aim of the current study is to report an outbreak of chronic Senecio spp. poisoning in sheep and to describe the clinical, gross, and histopathological aspects of the toxicosis. It is concluded that, taken together, the changes described here are diagnostic for the condition.

\section{MATERIALS AND METHODS}

The data of this report were obtained in a visit to the farm where the outbreak occurred. During that visit, eight affected sheep were clinically examined and subsequently euthanized and sub- mitted to necropsy, due the severity of clinical presentation. Seven out of the eight affected sheep were bled for liver function tests (aspartate aminotransferase [AST], gamma glutamyl transferase [GGT], alkaline phosphatase [AP]), and complete red cell count. Several tissues were sampled at necropsies and routinely processed for histopathology. Nine cattle of both sexes from the farm where this outbreak occurred were clinically examined and submitted to liver biopsy using a technique previously described (Barros et al. 2007). Liver samples were formalin-fixed and routinely processed for histology.

For the representative analysis of spongy degeneration in different regions of sheep brains, several transversal cuts were performed in a $0,5-1 \mathrm{~cm}$ interval. For histological evaluation the following transversal sections were systematically collected and processed: (1) Cerebellum and cerebellar peduncles; (2) pons; (3) frontal lobe; (4) parietal lobe; (5) occipital lobe; (6) medulla at the obex; (7) hippocampus; (8) basal nuclei; (9) mesencephalon; and (10) thalamus. Spongy degeneration was evaluated independently by two pathologists and classified as mild, moderate, and severe.

\section{RESULTS}

This outbreak occurred in a farm located in Santiago, Rio

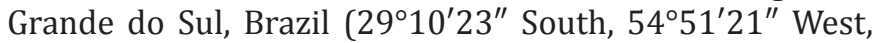
354 meters above sea level). Sheep and cattle were placed

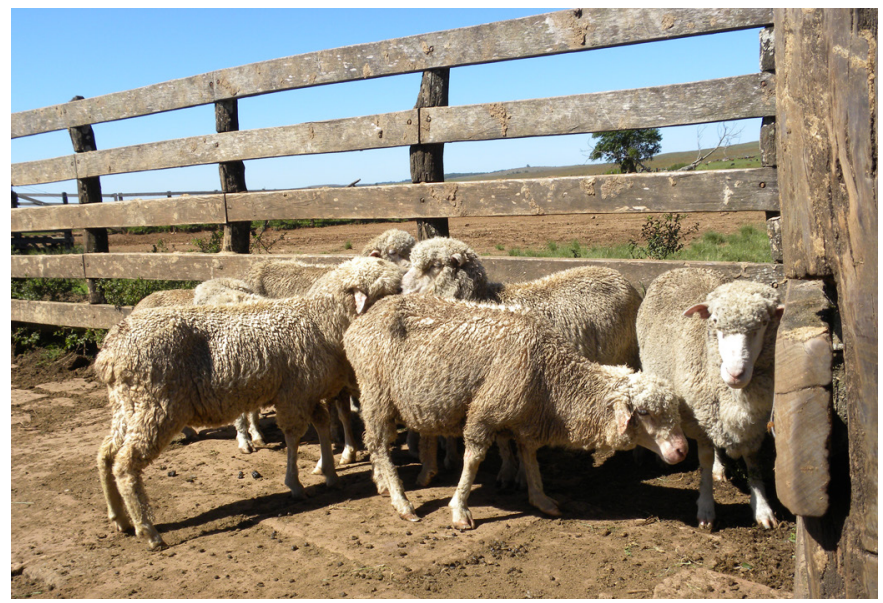

Fig.1. Sheep with poor body condition due to liver failure in Senecio spp. toxicosis.

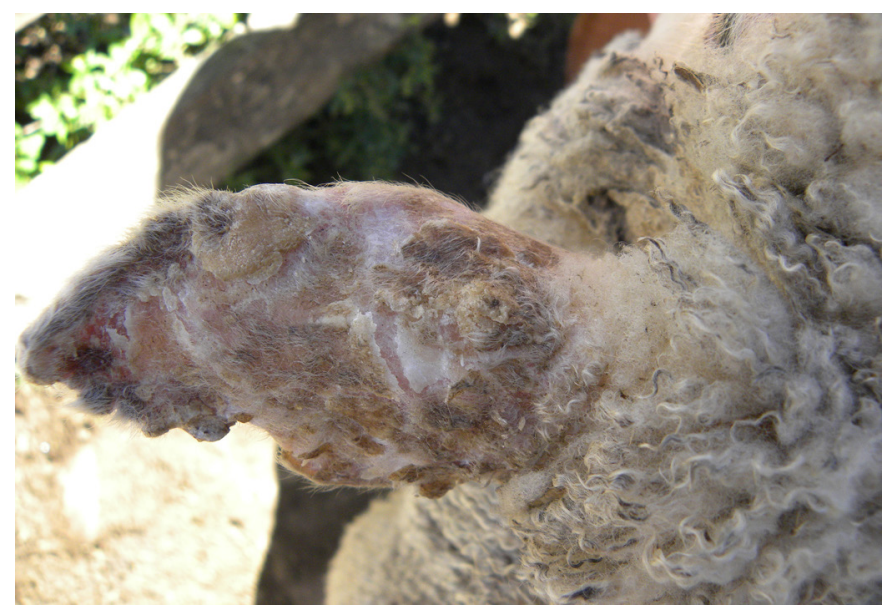

Fig.2. Crusts of the skin of the dorsum of ears. Photosensitivity in sheep due to liver failure in Senecio spp. toxicosis. 
in a pasture highly infested by Senecio spp., where they spent the winter (June to August) of 2013 under a shortage of forage caused by overgrazing. Ten sheep from a herd of 860 died since December 2013 to the end of March 2014 with clinical signs of progressive weight loss, apathy and photosensitization. Eight 2 to 4-year-old ewes were sick at the moment when the farm was visited by the authors on March 21, 2014. About 80 adult cattle from a herd of 1,300

Table 1. Results of biochemical tests compared with the severity of liver lesions observed in seven sheep poisoned by Senecio spp. ${ }^{a}$

\begin{tabular}{lcccc}
\hline Sheep & $\begin{array}{c}\text { Hepatic } \\
\text { lesion }\end{array}$ & $\begin{array}{c}\mathrm{AP}^{\mathrm{b}} \\
(68-387 \mathrm{U} / \mathrm{L}) \mathrm{c}\end{array}$ & $\begin{array}{c}\mathrm{AST}^{\mathrm{d}} \\
(20-280 \mathrm{U} / \mathrm{L})\end{array}$ & $\begin{array}{c}\mathrm{GGT}^{\mathrm{e}} \\
(20-52 \mathrm{U} / \mathrm{L})\end{array}$ \\
\hline 2 & + & 159 & 82 & 68 \\
3 & ++ & 228 & 94 & 43 \\
4 & + & 167 & 176 & 92 \\
5 & +++ & 157 & 146 & 21 \\
6 & + & 1178 & 77 & 111 \\
7 & + & 210 & 77 & 35 \\
8 & + & 1216 & 100 & 58
\end{tabular}

$\overline{\mathrm{a}+++ \text { severe },++}$ moderate, + mild, ${ }^{\mathrm{b}}$ alkaline phosphatase, ${ }^{\mathrm{c}}$ unit per liter (reference values from Hoffmann \& Solter 2008), ' aspartate aminotransferase, e gamma glutamyl transferase.
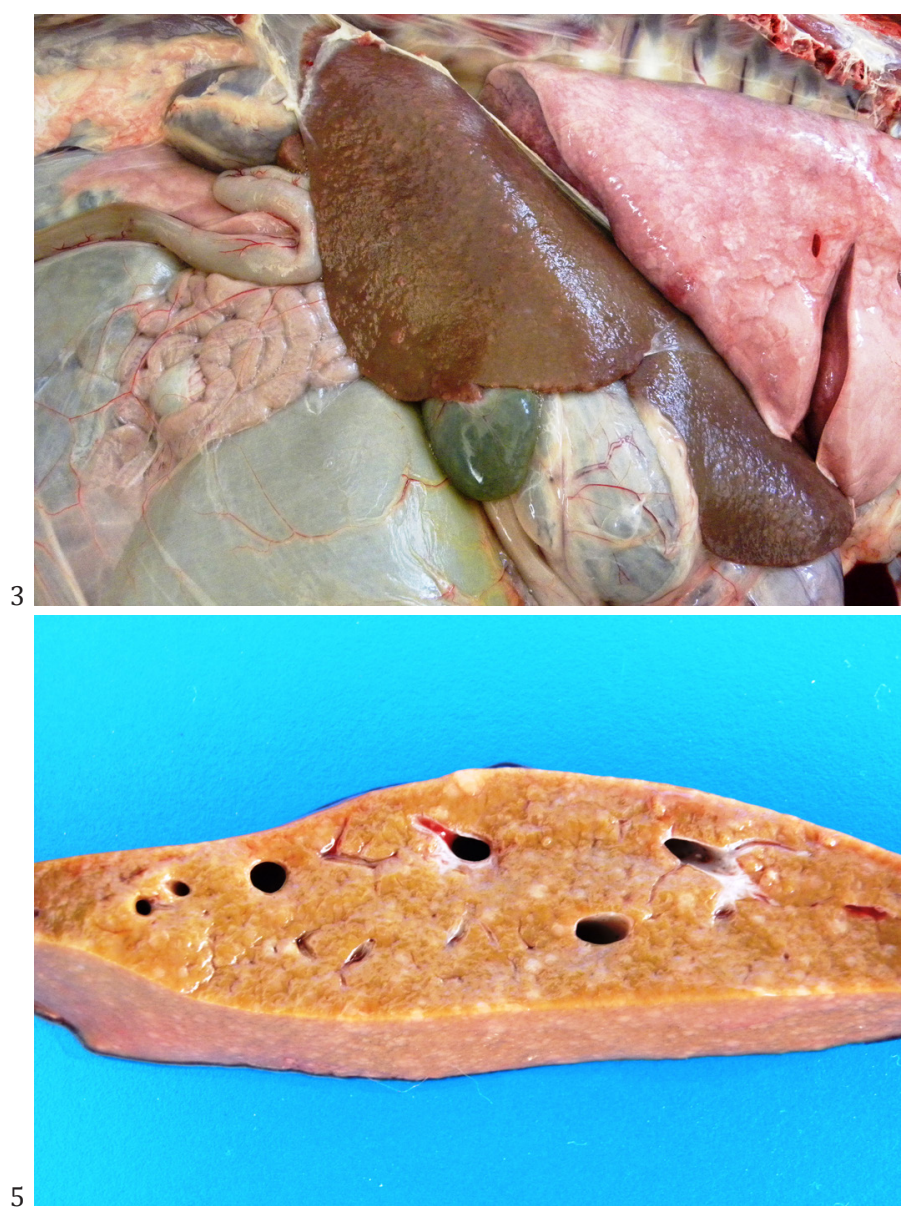

Fig.3. Liver with an irregular capsular surface in sheep with Senecio spp. toxicosis.

Fig.5. Cut surface of the liver showing multifocal tan nodules that range from $2-5 \mathrm{~mm}$ in diameter. Sheep with Senecio spp. toxicosis. died on this farm in 2013, presenting diarrhea, weight loss, and tenesmus. Some cattle also exhibited aggressiveness and photosensitization.

At clinical examination, ewes were apathetic, markedly thin (Fig.1), and presented slightly pale mucous membranes. All sheep had varying degrees of photodermatitis characterized by crusty lesions in the ears (Fig.2) and nose. Results of liver function tests are shown on Table 1. Red blood tests revealed mild normocytic normochromic anemia. At necropsy, three out of eight ewes presented a slightly irregular toughened liver (Fig.3 and 4). There were multifocal tan $2-5 \mathrm{~mm}$ in diameter nodules (Fig.5). In two out of the eight necropsied ewes the liver was whitish due to thickening of Glisson's capsule by fibrosis and portions of the parietal liver capsule were adhered to the diaphragm (Fig.6). No gross lesions could be detected in three out of the eight necropsied ewes. All the necropsied sheep had a distended gall bladder and mild abomasal infection by Haemonchus contortus. Other necropsy findings include hydropericardium (7/8), ascites (5/8), icterus (2/8), hydrothorax (1/8), and mesenteric edema $(1 / 8)$.

Varying degrees of microscopic changes attributed to alkaloid pyrrolizidine toxicosis were observed in the liver
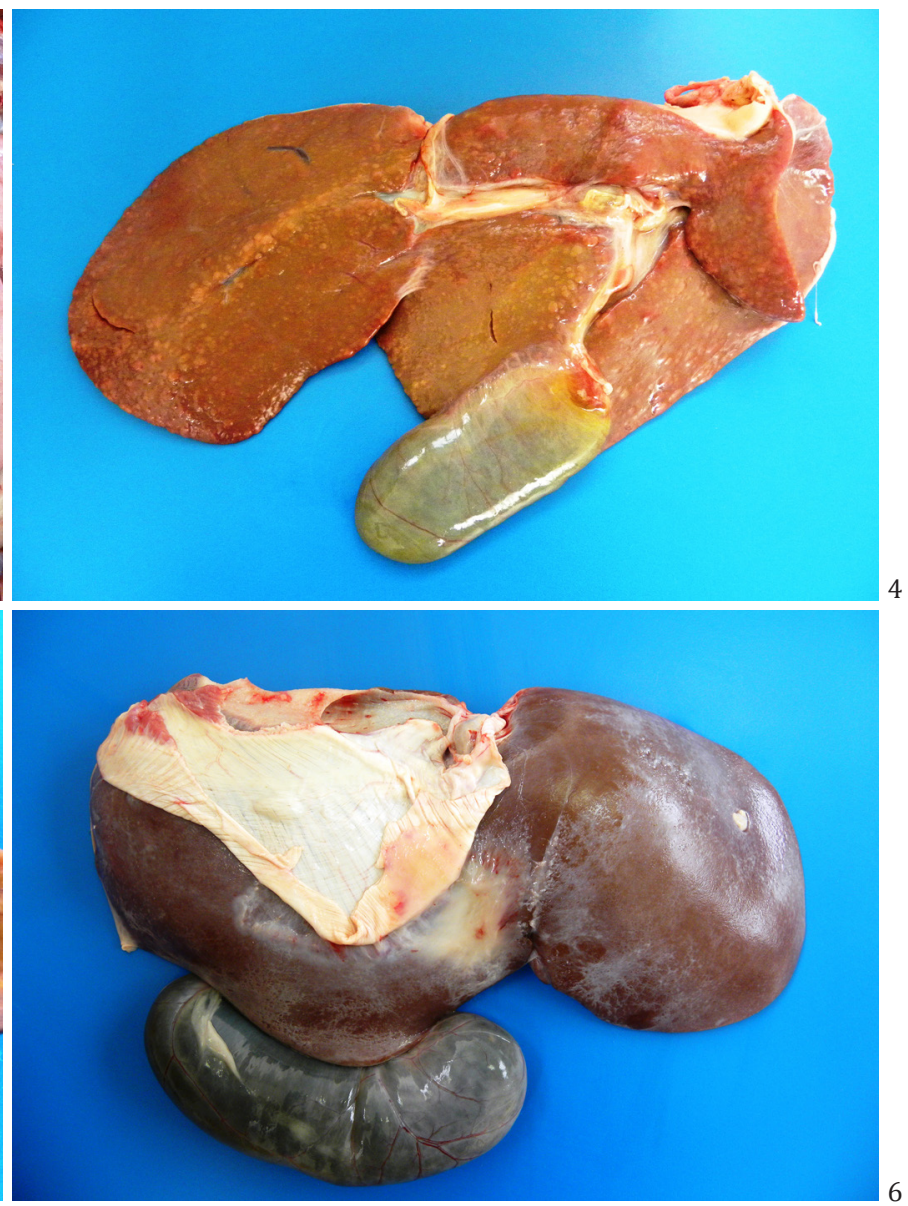

Fig.4. Visceral surface of the liver with multifocal to coalescing nodules and distended gall bladder in sheep with Senecio spp. toxicosis.

Fig.6. Liver of sheep affected by Senecio spp. toxicosis. Parietal surface of the liver showing whitish areas of fibrosis attached to the diaphragm. The gall bladder is markedly distended. 
of all eight necropsied ewes; these included fibrosis which ranged from periportal to dissecting some hepatocytes cords (Fig.7 and 8). Fibrosis was milder in the livers that were grossly normal. There was biliary duct hyperplasia in the portal triads (Fig.8) and Kupfer cells were hypertrophic. Hepatocytes were enlarged in size, with abundant cyto-
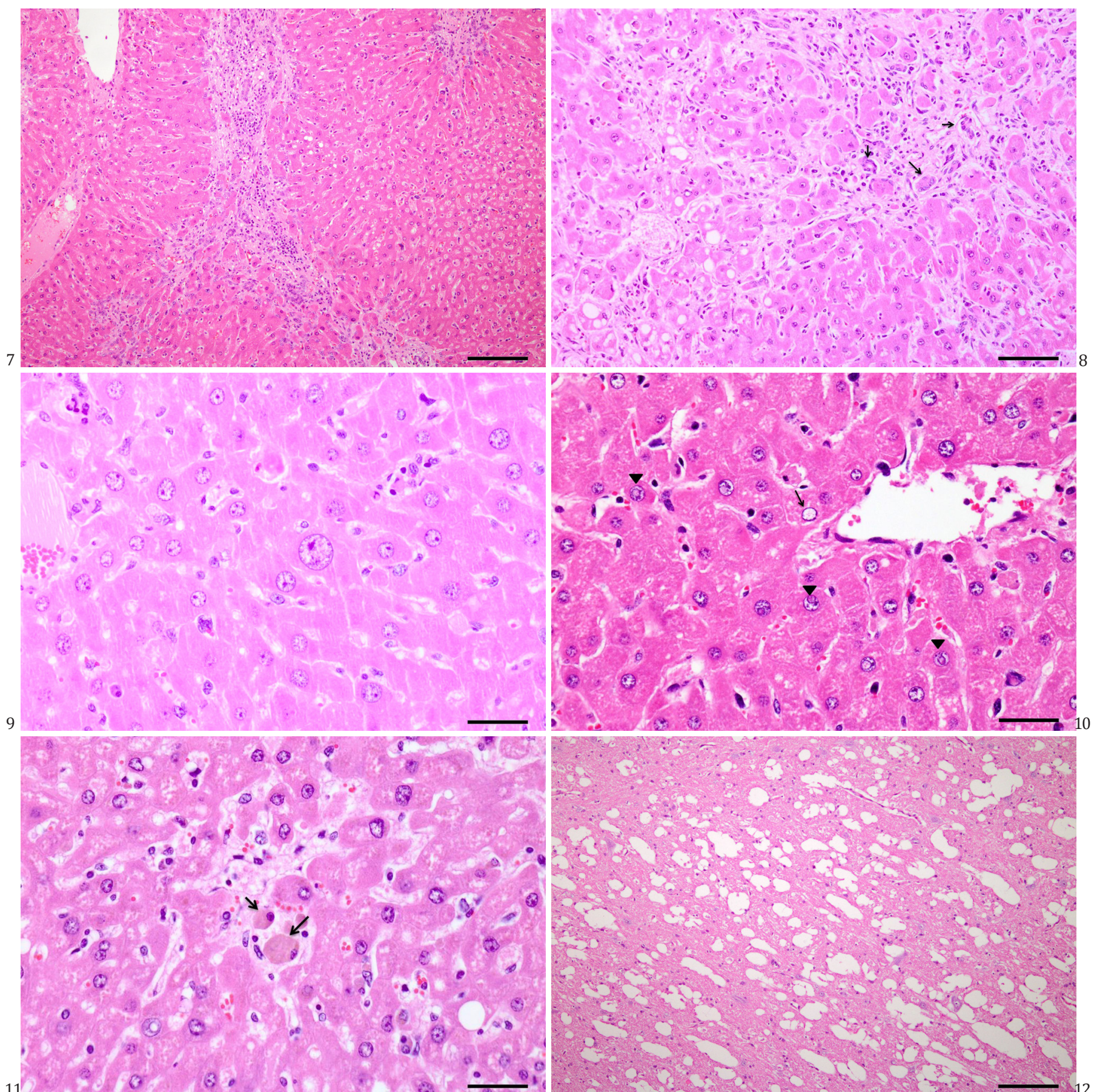

Fig.7. Histology of the liver of a sheep affected by Senecio spp. toxicosis. Portal tract is distended by fibrous connective tissue and biliary duct proliferation. HE, obj.10x.

Fig.9. Histology of the liver of a sheep affected by Senecio spp. toxicosis. Hepatocyte with an enlarged nucleus (megalocyte). HE, obj.40x.

Fig.11. Histology of the liver of a sheep affected by Senecio spp. toxicosis. Macrophages with brown and granular pigment in the cytoplasm interpreted as cooper and lipofuscin (arrows). HE, obj.40x.

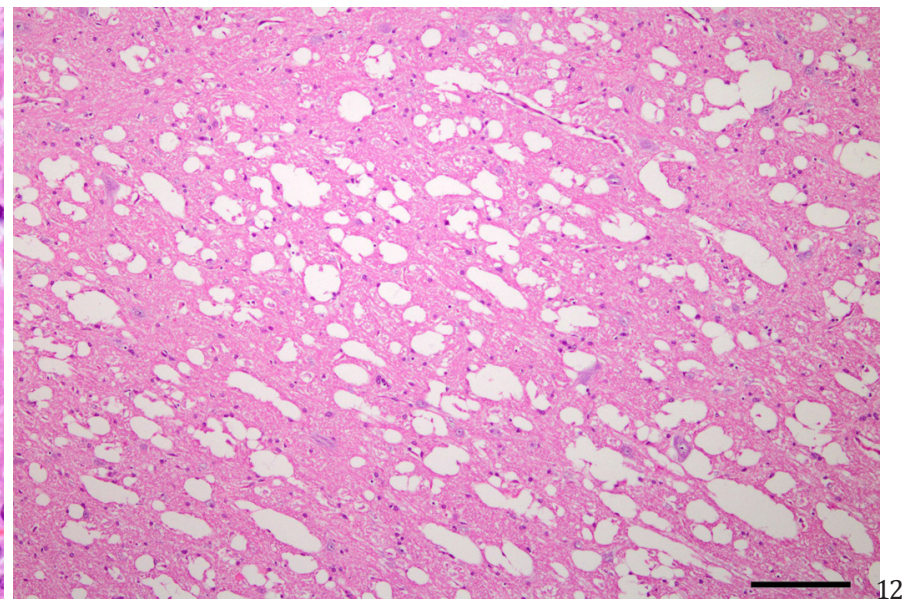

Fig.8. Histology of the liver of a sheep affected by Senecio spp. toxicosis. Cords of hepatocytes are dissected by connective tissue and there is marked hyperplasia of biliary ducts (arrows). HE, obj. 20x.

Fig.10. Histology of the liver of a sheep affected by Senecio spp. toxicosis. Nucleus of a hepatocyte (arrow) with a single vacuole displacing the nuclear chromatin to the periphery (empty nucleus). Numerous hepatocytes contained an oval, intranuclear, and eosinophilic inclusion (arrowheads). HE, obj.40x.

Fig.12. Histology of the brain (thalamus) of a sheep affected by Senecio spp. toxicosis. Severe spongy degeneration in the white matter. HE, obj.10x. 
Table 2. Distribution and severity of spongy degeneration in the brain of sheep with chronic poisoning by Senecio sp. Compared regarding the severity of hepatic lesions ${ }^{a}$

\begin{tabular}{|c|c|c|c|c|c|c|c|c|c|c|c|}
\hline Sheep & $\begin{array}{c}\text { Hepatic } \\
\text { lesion }\end{array}$ & $\begin{array}{l}\text { Cerebellum } \\
\text { and cerebellar } \\
\text { peduncle }\end{array}$ & Pons & $\begin{array}{c}\text { Frontal } \\
\text { lobe }\end{array}$ & $\begin{array}{c}\text { Parietal } \\
\text { lobe }\end{array}$ & $\begin{array}{c}\text { Occipital } \\
\text { lobe }\end{array}$ & Brainstem & Hypocampus & $\begin{array}{c}\text { Basal } \\
\text { nuclei }\end{array}$ & Mesencephalon & Thalamus \\
\hline 1 & + & +++ & +++ & ++ & + & $\mathrm{NC}^{\mathrm{b}}$ & ++ & $\mathrm{NC}$ & ++ & +++ & +++ \\
\hline 2 & + & +++ & +++ & ++ & ++ & + & ++ & NC & + & +++ & ++ \\
\hline 3 & ++ & +++ & +++ & ++ & ++ & $\mathrm{NC}$ & $\mathrm{NC}$ & $\mathrm{NC}$ & ++ & +++ & ++ \\
\hline 4 & + & +++ & +++ & ++ & + & $\mathrm{NC}$ & $\mathrm{NC}$ & $\mathrm{NC}$ & +++ & +++ & +++ \\
\hline 5 & +++ & +++ & +++ & + & + & $\mathrm{NC}$ & +++ & $\mathrm{NC}$ & +++ & +++ & +++ \\
\hline 6 & + & +++ & +++ & ++ & + & NC & +++ & $\mathrm{NC}$ & ++ & +++ & +++ \\
\hline 7 & + & +++ & +++ & ++ & + & $\mathrm{NC}$ & ++ & $\mathrm{NC}$ & ++ & +++ & + \\
\hline 8 & + & +++ & +++ & ++ & ++ & + & ++ & $\mathrm{NC}$ & ++ & +++ & +++ \\
\hline
\end{tabular}

plasm and large nuclei (Fig.9). Several nuclei had a single vacuole, displacing the nuclear chromatin to the periphery and giving an empty aspect to the nuclei. Numerous hepatocytes contained an oval, intranuclear, and eosinophilic inclusion (Fig.10). A variable number of macrophages with brown and granular pigment interpreted as cooper and lipofuscin in the cytoplasm was present (Fig.11). Nodules were not visible histologically.

Histological findings in the brain consisted of large empty spaces in the white matter in the brainstem, cerebellum, thalamus, basal nuclei and in the junction of the white and grey matter in the cerebrum (Fig.12). Distribution and severity of spongy degeneration in different cuts of the brains are shown on Table 2 .

Affected cattle submitted for clinical examination and liver biopsy on the day of the visit to the farm were in poor body condition and one of them presented edema in the submandibular region. Seven from nine biopsied cattle had typical hepatic histological lesions of pyrrolizidine alkaloids poisoning. There was disruption of hepatic architecture, where the cords and lobules were dissected by abundant connective tissue and fibrosis. There was marked hepatocellular megalocytosis and severe bile duct hyperplasia.

\section{DISCUSSION}

The clinical, epidemiological, gross and histopathological findings in sheep from this outbreak are similar to those previously described for chronic pyrrolizidine alkaloid (PA) poisoning in sheep (Ilha et al. 2001, Grecco et al. 2011). Sheep are believed to be relatively resistant to PA action due to ruminal detoxification (Craig et al. 1992) or to the low rates of pyrrole metabolite production coupled with high concentration of hepatic detoxifying enzymes system and efficient glutathione conjugation (Huan et al. 1998).

Although sheep grazing is considered efficient to control Senecio at pasture, if they are kept for several years under conditions of shortage of forage and in areas highly infested by plants containing pyrrolizidine alkaloids, they can get sick (Seaman 1985, Seaman \& Dixon 1989). The plants most often implicated with alkaloid pyrrolizidine toxicosis in sheep are Heliotropium europaeum and Echium plantagineum (Stalker \& Hayes 2007). In some regions of Australia, Echium plantagineum and Heliotropium europaeum poisoning is considered the main cause of death in sheep due to plant poisoning (St George-Grambauer \& Rac
1962, Seaman 1985, 1987). There are reports of Jacobaea maritima (formerly Senecio cineraria) poisoning in sheep in Iraq (Forsyth 1979), S. madagascariensis in Australia (Seaman 1987), and S. sanguisorbae in Mexico (Rosiles \& Paasch 1982). Clinical signs may not be seen until after a second season of exposure (Stalker \& Hayes 2007). Probably, poor management practices have resulted in the outbreak of seneciosis in sheep reported here, since cattle were also affected in the same farm.

Two different clinicopathological syndromes can affect sheep grazing plants containing pyrrolizidine alkaloids: (1) pyrrolizidine proper alkaloids poisoning (Seaman 1987) and (2) chronic copper poisoning secondary to pyrrolizidine alkaloids poisoning or hepatogenous chronic copper poisoning (Bull et al. 1956, St George-Grambauer \& Rac 1962, Seaman 1987). The chronic damage to hepatocytes results in an enhanced uptake and accumulation of copper in the liver (Bull et al. 1956) that under certain conditions can be released from the liver to the blood stream causing intravascular hemolysis (Stalker \& Hayes 2007). Hepatogenous chronic copper poisoning was not observed in sheep from the outbreak reported here, probably because sheep were euthanized or due to the fact they were not receiving copper-containing supplements. It is suggested that the occurrence of hepatogenous chronic copper poisoning associated with PA poisoning in sheep is related to an additional source of copper (Howell et al. 1991, Ilha et al. 2001).

The gross presentation of the livers from sheep with Senecio spp. poisoning was variable, consisting either of a multinodular aspect and thickened white capsule aspect, which is comparable with previous descriptions of Senecio spp. poisoning in sheep (Ilha et al. 2001, Grecco et al. 2011). It was noticed that the consistency of these livers was less firm than what is usually observed in cases of this condition in cattle. This difference is attributed to variable propensity to fibroplasia within species and to the degree of exposure; fibroplasia usually is minimal in sheep, moderate in horses and marked in cattle (Stalker \& Hayes 2007). Two sheep from this outbreak had grossly normal livers, although histological findings were characteristic of pyrrolizidine alkaloid poisoning. It is believed that these two cases represent an early stage of the disease.

The main histological findings in the liver that allowed the establishment of the diagnosis were hepatocellular polyploidy known as megalocytosis, proliferation of bile 
ducts epithelial cells in the portal triads, and periportal fibroplasia (Stalker \& Hayes 2007). Other histological features in the liver that additionally add in the diagnosis were the intranuclear inclusions and hepatocytes with empty nuclei.

Megalocytosis is the hallmark of PA toxicosis (Bull et al. 1969) and occurs as a consequence of pyrrolizidine alkaloid action, inhibiting DNA synthesis and mitosis in hepatocytes. However, some hepatocytes are able to produce DNA without mitosis, resulting in enlarged hepatocytes with large polyploid nuclei (Stalker \& Hayes 2007). Affected hepatocytes die and are replaced by cholangiolar epithelia that proliferate in response to regenerative stimuli when liver mass is inadequate (Stalker \& Hayes 2007). Hepatic fibrosis is evident in all animal species with chronic seneciosis (Kellerman et al. 2005) and it is initially seen in the portal tract (Walker \& Kirkland 1981, Torres \& Coelho 2008).

Intranuclear inclusions in pyrrolizidine alkaloid poisoning correspond to part of the cytoplasm that is sometimes invaginated by the enlarged nuclei (Kellerman et al. 2005, Stalker \& Hayes 2007). Hepatocytes described as having a single nuclear vacuole displacing the nuclear chromatin (empty nuclei) were similar to those seen in great number in human beings with Wilson disease, diabetes mellitus, prolonged congestive heart failure, and some other disorders (Geller \& Petrovic 2009). These "glycogen nuclei" or glycogenated nuclei are present in small numbers in humans with no recognizable disease. The normal hepatocyte also contains abundant glycogen which is not seen with hematoxylin-eosin but is easily demonstrated with the PAS reaction (Geller \& Petrovic 2009).

Spongy degeneration was observed in all the brains and was more severe in cerebellar peduncles, mesencephalon, thalamus, and pons, according to previous descriptions in sheep (Hooper 1975, Ilha et al. 2001, Kellerman et al. 2005) and cattle (Wouters et al. 2013). Apparently, no neurological signs were observed in any of the sheep as also recognized elsewhere (Kellerman et al. 2005). This can also be associated with the fact that sheep were euthanized and the whole clinical course was not observed, but the most probable explanation is that very often neurological disease manifested by sheep with brain lesions are not conspicuous and manifest solely as apathy.

Morphological changes in hepatic encephalopathy in the central nervous system of human beings and horses centers on astrocytes (Harris et al. 2008, Crawford 2005). Astrocytes undergo Alzheimer type II change in which they show enlarged pale nuclei with a rim of chromatin and prominent nucleoli. Astrocytes pairs and triplets are seen, and in severe cases nuclei may become lobulated and may contain glycogen (Stalker \& Hayes 2007, Harris et al. 2008). Cirrhosis of the liver results in elevated ammonia levels in blood and brain and it is the ammonia toxicity that is the leading hypothesis for the causation of hepatic encephalopathy (Harris et al. 2008). An astrocytic phenotype similar to Alzheimer type II change can be induced by hyperammonemia in experimental animals and tissue culture and is also seen in human patients with congenital hyperammo- nemia due to inherited disorders involved in the urea cycle (Butterworth 1993). Morphological findings in ruminants with hepatic encephalopathy are characterized by microcavitation of the white matter in the brain named status spongiosus or spongy degeneration (Finn \& Tennant 1974, Barros 2010). The spongy change is due to intramyelinic edema, causing splitting and vacuolation of myelin sheaths (Zachary 2012).

Serum liver enzyme activities were variable in these sheep. Four out seven tested sheep had increase in GGT serum activity and two out of seven sheep presented increased serum activity of AP. Enzymatic elevation were not proportional to liver injury observed. It is known that serum enzyme changes precede development of recognizable histologic lesions in the liver of calves with chronic seneciosis and serum glutamate dehydrogenase is the first enzyme to increase in most animals (Craig et al. 1991). This enzyme change is followed by increases in alkaline phosphatase and gamma-glutamyl transferase (Craig et al. 1991). It is concluded that elevations of GGT activities could be used to predict the onset of clinical illness in sheep. Findings of normocytic normochromic anemia in red blood tests of sheep from the current outbreak were attributed to Haemonchus contortus infection (Abott et al. 1984).

In conclusion, histological changes are the most important features for the diagnosis of Senecio spp. poisoning in sheep and differential diagnosis must be made with poisoning by other plants that contains pyrrolizidine alkaloids.

Aknowledgements.- This study was funded by grant 482509/2012-0 from Conselho Nacional de Desenvolvimento Científico e Técnológico (CNPq).

\section{REFERENCES}

Abott E.M., Parkins J.J. \& Holmes P.H. 1984. Studies on the pathophysiology of chronic ovine haemonchosis in Merino and Scottish blackface lambs. Parasitol. 89:585-596.

Bandarra P.M., Oliveira L.G., Dalto A.C., Boabaid F.M., Juffo G., Riet-Correa F., Driemeier D. \& Cruz C.E.F. 2012. Sheep production as a Senecio spp. control tool. Pesq. Vet. Bras. 32:1017-1022.

Barros C.S.L., Castilhos L.M.L., Rissi D.R., Kommers G.D. \& Rech R.R. 2007. Biópsia hepática no diagnóstico da intoxicação por Senecio brasiliensis (Asteraceae) em bovinos. Pesq. Vet. Bras. 27:53-60.

Barros C.S.L. 2010. Fígado e vias biliares, p.276-281. In: Santos R.L. \& Alessi A.C. (Eds), Patologia Veterinária. Roca, São Paulo. 892p.

Bull L.B., Dick A.T., Keast J.C. \& Edgar G. 1956. An experimental investigation of the hepatotoxic and other effects on sheep of consumption of Heliotropium europaeum L: heliotrope poisoning of sheep. Aust. J. Agric. Res. 9:281-336.

Bull L.B., Culvenor C.C.J. \& Dick A.T. 1969. The pyrrolizidine alkaloids: their chemistry, pathogenicity and other biological properties. North Holland Publ., Amsterdam.

Butterworth R.F. 1993. Portal-systemic encephalopathy: a disorder of neuron astrocytic metabolic trafficking. Dev. Neurosci. 15:313-319.

Craig A.M., Pearson E.G., Meyer C. \& Schmitz J.A. 1991. Serum liver enzyme and histopathologic changes in calves with chronic and chronic-delayed Senecio jacobaea toxicosis. Am. J. Vet. Res. 52:1969-1978.

Craig A.M., Lathan C.J., Blythe L.L., Schmotzer W.B. \& O'Connor O.A. 1992. Metabolism of toxic pyrrolizidine alkaloids from tansy ragwort (Seneciojacobaea) in ovine ruminal fluid under anaerobic conditions. Appl. Environ. Microbiol. 58:2730-2736. 
Crawford J.M. 2005. Fígado e trato biliar, p.924. In: Kumar V., Abbas A.K. \& Fausto N. (Eds), Robbins and Cotran Bases Patológicas das Doenças. $7^{\text {th }}$ ed. Elsevier Inc., Philadelphia.

Dollahite J.W. 1972. The use of sheep and goats to control Senecio poisoning in cattle. Southwest. Vet. 25:223-226.

Finn J.P. \& Tennant B. 1974. Hepatic encephalopathy in cattle. Cornell Vet. 64:137-153.

Forsyth A.A. 1979. British Poisonous Plants. $2^{\text {nd }}$ ed. Bull. 161, Ministry Agriculture, Fishery and Food, London, p.98-102.

Geller S.A. \& Petrovic L.M. 2009. Biopsy interpretation of the liver. $2^{\text {nd }}$ ed. Lipincott Williams and Wilkins, Philadelphia, p.30.

Grecco F.B., Estima-Silva P., Marcolongo-Pereira C., Soares M.P., Collares G. \& Schild A.L. 2011. Seneciose crônica em ovinos no sul do Rio Grande do Sul. Pesq. Vet. Bras. 31:326-330.

Harris J., Chimelli L., Kril J. \& Ray D. 2008. Hepatic encephalopathy, p.693694. In: Love S., Louis D.N. \& Ellison D.W. (Eds), Greenfield's Neuropathology. Vol.1. $8^{\text {th }}$ ed. Hodder Arnold, London.

Hoffmann W. \& Solter P.F. 2008. Diagnostic enzymology of domestic animals, p.359-360. In: Kaneko J.J., Harvey J.W. \& Bruss M.L. (Eds), Clinical Biochemistry of Domestic Animals. $6^{\text {th }}$ ed. Academic Press, San Diego.

Hooper P.T. 1975. Spongy degeneration in the central nervous system of domestic animals. II. Chemical analysis and vascular permeability studies. Acta Neuropathol. 31:335-341.

Howell J. McC., Deol H.S., Dorling P.R. \& Thomas J.B. 1991. Experimental copper and heliotrope intoxication in sheep: morphological Changes. J. Comp. Pathol. 105:49-74.

Huan J.Y., Miranda C.L., Buhler D.R. \& Cheeke P.R. 1998. Species differences in the hepatic microsomal enzyme metabolism of the pyrrolizidine alkaloids. Toxicol. Lett. 99:127-137.

Ilha M.R.S., Loretti A.P., Barros S.S. \& Barros C.S.L. 2001. Intoxicação espontânea por Senecio brasiliensis (Asteraceae) em ovinos no Rio Grande do Sul. Pesq. Vet. Bras. 21:123-138.

Karam F.C., Moraes J.C.F. \& Schild A.L. 2013. Controle de Senecio spp. com pastoreio ovino de acordo com sua infestação e fenologia. Pesq. Vet. Bras. 33:1109-1115.

Kellerman T.S., Coetzer J.A.W., Naudé T.W. \& Botha C.J. 2005. Hepatoxicosis without photosensitivity, p.3-24. In: Ibid. (Eds), Plant Poisonings and
Mycotoxicoses of Livestock in Southern Africa. $2^{\text {nd }}$ ed. University of Oxford, Oxford, UK.

Lucena R.B., Pierezan F., Kommers G.D., Irigoyen L.F., Fighera R.A. \& Barros C.S.L. 2010. Doenças de bovinos no Sul do Brasil: 6.706 casos. Pesq. Vet. Bras. 30:428-434

Rosiles R. \& Paasch L.H. 1982. Megalocitosis hepática en ovinos. Vet. Mexico 13:151-153.

Seaman J.T. 1985. Hepatogenous chronic copper poisoning in sheep associated with grazing Echium plantagineum. Aust. Vet. J. 62:247-248.

Seaman J.T. 1987. Pyrrolizidine alkaloid poisoning of sheep in New South Wales. Aust. Vet. J. 64:164-167.

Seaman J.T. \& Dixon R.J. 1989. Investigations into the toxicity of Echium plantagineum in sheep. 2. Pen feeding experiments. Aust. Vet. J. 66:286-292.

St George-Grambauer T.D. \& Rac R. 1962. Hepatogenous chronic copper poisoning in sheep in South Australia due to the consumption of Echium plantagineum L. (Salvation jane). Aust. Vet. J. 45:288-293.

Stalker M.J. \& Hayes M.A. 2007. Pyrrolizidine alkaloids, p.373-376. In: Maxie M.G. (Ed.), Jubb, Kennedy and Palmer's Pathology of Domestic Animals. Vol.2. $5^{\text {th }}$ ed. Academic Press, San Diego.

Soares M.P., Riet-Correa F., Méndez M.C., Rosa F.G. \& Carreira E.G. 2000. Controle biológico de Senecio spp. com pastoreio de ovinos. Anais da II Reunión Argentina de Patologia Veterinária, Facultad de Ciências Veterinárias, Universidad Nacional Del Nordeste, Corrientes, Argentina, p.79. (Resumo)

Torres M.B.A.M. \& Coelho K.I.R. 2008. Experimental poisoning by Senecio brasiliensis in calves: quantitative and semi-quantitative study on changes in the hepatic extracellular matrix and sinusoidal cells. Pesq. Vet. Bras. 28:43-50.

Tokarnia C.H., Döbereiner J. \& Peixoto P.V. 2002. Poisonous plants affecting livestock in Brazil. Toxicon 40:1635-1660.

Walker K.H. \& Kirkland P.D. 1981. Senecio lautus toxicity in cattle. Aust. Vet. J. 57:1-7.

Wouters A.T.B., Boabaid F.M., Fredo G., Wouters F. \& Driemeier D. 2013. Caracterização imuno-histoquímica das alterações encefálicas em bovinos com hepatopatia tóxica por Senecio sp. Pesq. Vet. Bras. 33:1325-1331.

Zachary J.F. 2012. Nervous system, p.815. In: Zachary J.F. \& McGavin M.D. (Eds), Pathologic Basis of Veterinary Disease. $5^{\text {th }}$ ed. Elsevier, St Louis. 